\title{
ANALISIS FAKTOR-FAKTOR YANG MEMENGARUHI KEPUTUSAN MAHASISWA MEMILIH PROGRAM PASCASARJANA
}

\section{ANALYSIS OF FACTORS THAT INFLUENCE STUDENT DECISIONS CHOOSING POSTGRADUATE PROGRAMS}

\author{
Mahmudah $^{1 a}$, Lukman Mohammad Baga ${ }^{1}$, Siti Amanah ${ }^{1}$ \\ ${ }^{1}$ Departemen Agribisnis, Fakultas Ekonomi dan Manajemen, Institut Pertanian Bogor, \\ Jl. Kamper, Wing 4 Level 5, Kampus IPB Dramaga, Bogor 16680 \\ ${ }^{1}$ Departemen SKPM, Fakultas Ekologi Manusia, Institut Pertanian Bogor, \\ Jl. Kamper, Wing 1 Level 5, Kampus IPB Dramaga, Bogor 16680 \\ a'Korespondensi: Mahmudah, Telp/Hp: 082111584554, E-mail: arkanadha@gmail.com
}

\begin{abstract}
The study aimed to determine factors influence the decision making the process of the students to choose master or doctorate programs at the at Department of Resources and Environmental Economics, FEM IPB. This research was conducted by using the quantitatively descriptive analysis and multiple regression analysis methods. A survey to 54 the students of Magister and a survey to 51 the students of Doctor was administered to learn the reason of the students took the final decision to the further study at the at Department of Resources and Environmental Economics, FEM IPB. The variables observed were the product, price, location, promotion, process, people, physical evidence, assignments from workplace institutions, availability of sponsors, self-motivation. The data collection technique used was the distribution of questionnaires, namely using the google form that was disseminated through student e-mail, social media and direct distribution to students. Based on the results of the research the decision making process of graduate students to choose the graduate programs are through five steps. Based on the research results of the factors that have a significant effect on the decision of students to choose the Postgraduate Program at the at Department of Resources and Environmental Economics, FEM IPB are products (Study Program), promotion and self-motivation (students).
\end{abstract}

Keywords: factors influence, student decision, postgraduate programs

\begin{abstract}
ABSTRAK
Tujuan penelitian yang dilakukan adalah untuk mengetahui lebih dalam proses pengambilan keputusan mahasiswa memilih Program Magister dan Doktor Pascasarjana dan untuk mengetahui faktor-faktor yang memiliki pengaruh terhadap keputusan mahasiswa memilih Program Pascasarjana di Departemen ESL FEM IPB. Penelitian dilakukan dengan menggunakan metode analisis deskriptif kuantitatif dan analisis regresi berganda, sedangkan yang menjadi informan penelitian adalah mahasiswa aktif pada Program Pascasarjana di Departemen ESL FEM IPB berjumlah 54 orang mahasiswa Program Magister dan 51 orang mahasiswa Program Doktor. Variabel penelitian adalah produk, harga, lokasi, promosi, proses, orang, bukti fisik, penugasan dari lembaga tempat bekerja, ketersediaan sponsor, dan kemauan sendiri. Data yang dikumpulkan menggunakan teknik penyebaran kuesioner melalui google form yang disebar dengan email mahasiswa, media sosial dan penyebaran langsung ke mahasiswa. Hasil penelitian menunjukkan bahwa proses mahasiswa mengambil keputusan mahasiswa memilih Program
\end{abstract}


Pascasarjana melalui lima tahap. Faktor yang memiliki pengaruh signifikan terhadap keputusan mahasiswa memilih Program Pascasarjana di Departemen ESL FEM IPB adalah produk (Program Studi), promosi dan kemauan sendiri (mahasiswa).

Kata kunci: faktor-faktor yang mempengaruhi, keputusan mahasiswa, program pascasarjana

Mahmudah, Baga, L.M., \& Amanah, S. (2019) Analisis Faktor-Faktor Yang Memengaruhi Keputusan Mahasiswa Memilih Program Pascasarjana. Tadbir Muwahhid, 3(2), 97-117

\section{PENDAHULUAN}

Berdasarkan SK Rektor IPB No. 001/K13/PP/2005 tanggal 10 Januari 2005 Departemen ESL adalah pengelola unit yang memiliki mandat dalam mengembangkan ilmu ekonomi pertanian secara luas yaitu perikanan, peternakan, pertanian dan kehutanan. Departemen ESL mengelola tiga Program Studi Pascasarjana, yaitu Program Magister dan Doktor Ilmu Ekonomi Pertanian (PS-EPN), Program S2 dan S3 Ekonomi Kelautan Tropika (PS-EKT), dan Program Magister Ekonomi Sumberdaya dan Lingkungan (PS-ESL). Salah satu input dalam penyelenggaraan Program Studi Pascasarjana adalah mahasiswa. Perkembangan jumlah mahasiswa Program Pascasarjana di Departemen ESL FEM IPB pada 5 (lima) tahun terakhir ini mengalami penurunan. Penurunan jumlah mahasiswa ini perlu diperhatikan karena di Indonesia, banyaknya peminat dan jumlah mahasiswa sesuai dengan kapasitas yang mereka miliki merupakan salah satu keberhasilan dari perguruan tinggi (Harwani et al. 2018).

Perkembangan jumlah mahasiswa Program Pascasarjana di Departemen ESL
FEM IPB dapat dilihat pada Gambar 1. Gambar 1 menunjukkan penurunan jumlah mahasiswa Program Pascasarjana di Departemen ESL FEM IPB periode penerimaan Tahun Ajaran 2014/2015 hingga Tahun Ajaran 2018/2019. Penurunan jumlah mahasiswa secara signifikan terjadi pada Program Doktor PS-EKT dengan banyaknya mahasiswa berjumlah 1 orang. Jumlah kenaikan mahasiswa yang signifikan terjadi pada tahun 2014/2015 pada Program Magister PS-ESL dengan jumlah 27 orang.

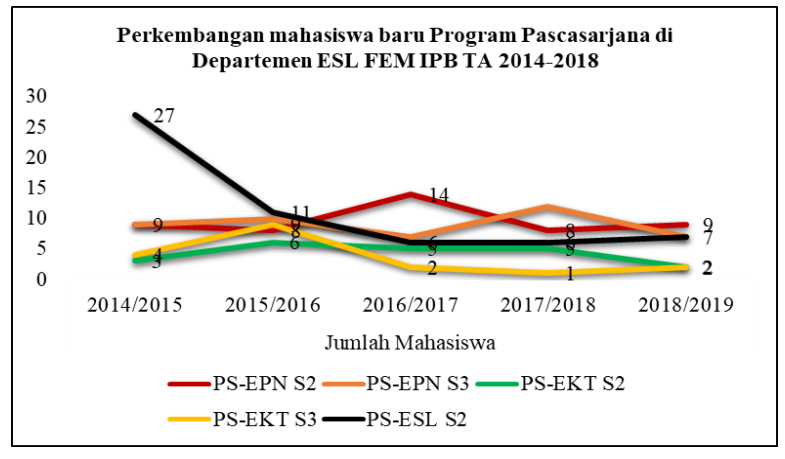

Gambar 1 Perkembangan mahasiswa baru Program Pascasarjana di Departemen ESL FEM IPB TA 2014-2018

Sumber: Borang Akreditasi Program Studi Pascasarjana Departemen ESL FEM IPB 2018.

Era globalisasi mendorong ilmu pengetahuan dan teknologi berkembang 
sangat cepat, sehingga membuat semua informasi sangat mudah di akses dan tanpa batas. Informasi penyelenggaraan pendidikan Program Pascasarjana baik di dalam negeri maupun di luar negeri sangat mudah di dapatkan. Mahasiswa dapat dengan mudah memperoleh informasi mengenai Program Studi Pascasarjana yang akan dipilihnya. Informasi pendaftaran melalui online Program Studi Pascasarjana sudah hampir dilakukan di perguruan tinggi seluruh Indonesia. Persaingan yang tinggi antara perguruan tinggi di Indonesia baik negeri maupun swasta dalam rangka menarik minat mahasiswa dan tingginya perkembangan teknologi komunikasi informasi mengakibatkan cepatnya mengalir informasi ke masyarakat, sehingga perguruan tinggi harus sigap menampilkan Program Studi kompetitif untuk ditawarkan kepada masyarakat. Penawaran perkuliahan dengan sistem online juga telah dilaksanakan oleh banyak perguruan tinggi terbaik di berbagai wilayah Indonesia (Topan 2018). Wijaya (2012) mengemukakan bahwa memanfaatkan unsur bauran pemasaran merupakan salah satu cara untuk memperoleh dan mempertahankan keunggulan kompetitif pada jasa pendidikan. Menurut Purwanto dan Rahayu (2014) bahwa suatu hal yang penting untuk memenangkan pasar persaingan bisnis di bidang jasa adalah mengetahui kebutuhan dan keinginan masyarakat, khususnya pasar perguruan tinggi yang akan terus mengalami perubahan seiring dengan pola pikir masyarakat yang dinamis dan adanya perubahan pada kekuatan global.

Perilaku konsumen erat kaitannya dengan pemasaran, menurut Angipora (2002) ada dua faktor yang mempengaruhi pemasaran secara keseluruhan yaitu faktor lingkungan internal dan lingkungan eksternal. (1) Lingkungan internal adalah pengaruh yang bersumber dari dalam perusahaan, yang akan secara langsung mempengaruhinya pada kinerja keseluruhan bagian perusahaan. Salah satu faktor dalam lingkungan internal adalah marketing mix. Zeithmal dan Bitner dalam Hurriyati (2015) bahwa marketing mix untuk jasa yaitu product, price, place, promotion, people, physical evidence dan process. (2) Lingkungan eksternal adalah berpengaruhnya lingkungan dari luar perusahaan baik lingkungan yang sangat dekat dengan perusahaan maupun lingkungan yang agak jauh, secara langsung atau tidak langsung mempengaruhi kegiatan perusahaan secara keseluruhan. Artini et al. (2014) bahwa lingkungan eksternal yang perlu menjadi perhatian adalah keluarga, kemauan sendiri dan kelompok acuan.

Penelitian yang dilakukan Sukendar (2015) hasilnya menyatakan bahwa faktorfaktor yang signifikan memiliki pengaruh terhadap keputusan mahasiswa memilih program studi adalah produk dan promosi. Erdawati (2014) dalam penelitiannya dengan 
analisis regresi linier berganda menunjukkan bahwa faktor yang mempunyai pengaruh terhadap keputusan mahasiswa memilih Sekolah Tinggi Ilmu Ekonomi Simpat Empat adalah variabel promosi. Menurut hasil penelitian Harahap (2015) mengemukakan bahwa salah satu faktor yang mempunyai pengaruh signifikan terhadap keputusan mahasiswa dalam memilih jurusan Akuntansi adalah faktor pribadi. Penelitian Wulandini dan Saputra (2017) menyatakan bahwa diantara variabel yang mempunyai hasil pengaruh signifikan terhadap pengambilan keputusan mahasiswa menentukan perguruan tinggi swasta di Pekanbaru adalah promosi. Penelitian Wiliana (2018) menyatakan bahwa beberapa variabel yang menunjukkan pengaruh signifikan terhadap keputusan mahasiswa mengambil Program Studi adalah faktor internal (harga, produk, lokasi, promosi) dan faktor eksternal (pendapatan keluarga dan kemauan sendiri). Rahardjo dan Firdaus (2015) dalam penelitiannya mengemukakan bahwa adanya pengaruh yang signifikan bauran pemasaran (produk, harga, promosi, lokasi, proses, orang dan tampilan fisik) terhadap keputusan mahasiswa menentukan studi pada LP3I Business College Banjarmasin.

Engel et al. (1995) menyatakan bahwa dengan memahami perilaku konsumen, perguruan tinggi bisa membuat strategi pemasaran yang sesuai dalam rangka menggunakan peluang yang ada. Perilaku konsumen berhubungan erat dengan cara mahasiswa mengambil keputusan untuk memakai barang atau jasa dalam memuaskan kebutuhannya (Hurriyati 2015). Marjanovic dan Pavlovic (2018) menyatakan bahwa lima proses tahap pengambilan keputusan pembelian Kotler diterapkan pada mahasiswa yang akan memutuskan memilih perguruan tinggi. Penelitian mengenai perilaku konsumen, terutama tentang pilihan juga proses mahasiswa menetapkan pilihan, membantu perguruan tinggi untuk memiliki pemahaman yang jelas mengenai pasar rekrutmen mahasiswa (Arifin et al. 2017). Pengkajian perilaku konsumen melalui proses keputusan mahasiswa menentukan studi dan faktor-faktor yang memengaruhi keputusan mahasiswa memilih Program Pascasarjana di Departemen ESL FEM IPB perlu dilakukan karena hal tersebut dapat membantu Program Pascasarjana dalam strategi pengembangan Program Studi untuk meningkatkan jumlah mahasiswa.

\section{METODE}

\section{Jenis Penelitian}

Jenis penelitian dilakukan menggunakan metode deskriptif kuantitatif. Analisis deskriptif kuantitatif digunakan untuk memberikan gambaran perilaku mahasiswa dalam proses mengambil keputusan memilih program pascasarjana dan mendeskripsikan 
karakteristik individu mahasiswa Magister (S2) dan Doktor (S3) yang dijadikan sebagai sampel. Analisis deskriptif juga digunakan untuk menggambarkan proses mahasiswa mengambil keputusan memilih pendidikan Pascasarjana di Departemen ESL serta implikasi pengaruh faktor-faktor yang memengaruhi pengambilan keputusan mahasiswa dalam upaya menambah jumlah mahasiswa baru.

\section{Waktu dan Tempat Penelitian}

Penelitian dilakukan mulai tanggal 12 Maret 2019 sampai dengan 12 April 2019 bertempat pada Program Pascasarjana di Departemen Ekonomi Sumberdaya dan Lingkungan (ESL), Fakultas Ekonomi dan Manajemen (FEM), Institut Pertanian Bogor.

\section{Target/Subjek Penelitian}

Populasi penelitian adalah mahasiswa aktif Program Pascasarjana di Departemen ESL FEM IPB Tahun Akdemik 2018/2019 sejumlah 153 mahasiswa. Pengambilan sampel dilakukan dengan tabel penentuan jumlah sampel dari populasi tertentu yang dikembangkan dari Isaac dan Michael dengan taraf kesalahan $1 \%, 5 \%$, dan $10 \%$. Sugiyono (2007) mengemukakan bahwa untuk menghitung ukuran sampel dari populasi yang diketahui jumlahnya dengan menggunakan rumus sebagai berikut:

$\mathrm{S}=\frac{\lambda^{2} \cdot N \cdot P \cdot Q}{\mathrm{~d}^{2}(\mathrm{~N}-1)+\lambda^{2} \cdot P \cdot Q}$
Keterangan:

$\lambda^{2}$ dengan $\mathrm{dk}=1$, taraf kesalahan $1 \%, 5 \%$, $10 \%$

$P=Q=0,5 \cdot d=0,05 . s=$ jumlah sampel

Berdasarkan rumus tersebut dengan taraf kesalahan 5\%, maka sampel yang dijadikan responden sebanyak 105 mahasiswa aktif Program Magister dan Program Doktor Tahun Akademik 2018/2019 Program Pascasarjana di Departemen ESL FEM IPB.

Metode dalam mengambil sampel adalah proportionate stratified random sampling, yaitu metode mengambil sampel yang memiliki strata proporsional dari setiap kelompok populasi yang digunakan menjadi sampel dan pengambilan sampel dilakukan secara acak. Banyaknya sampel yang diambil berdasarkan strata program yang dipilih oleh mahasiswa aktif. Jumlah responden dapat dilihat pada Tabel 1 .

Tabel 1 Jumlah responden berdasarkan kriteria strata Program

\begin{tabular}{cccc}
\hline Program & Populasi & Taraf 5 $\%$ & Sampel \\
\hline S2 & 79 & 105 & 54 \\
S3 & 74 & 105 & 51 \\
\hline Total & 153 & & 105 \\
\hline
\end{tabular}

Tabel 1 menunjukkan penentuan sampel pada setiap kelompok berdasarkan jumlah populasi mahasiswa pada Program S2 dan S3 dibagi dengan jumlah total populasi 
mahasiswa kemudian dikalikan dengan taraf kesalahan $5 \%$.

\section{Prosedur Penelitian}

Data dan informasi dari responden dikumpulkan menggunakan instrumen kuesioner yang terstruktur (structured questionnare). Pertanyaan diajukan kepada responden, dimana responden mengisi jawaban terhadap pertanyaan tersebut (Sumarwan et al. 2013). Jawaban beberapa pertanyaan terstruktur dibuat berdasarkan skala Likert 1-5. Penyebaran kuesioner dijalankan dengan google form yang disebar melalui email mahasiswa, media sosial dan penyebaran langsung ke mahasiswa. Jumlah sampel yang diambil berdasarkan strata program yang telah ditentukan oleh mahasiswa aktif sebanyak 54 orang mahasiswa Program Magister dan 51 orang mahasiswa Program Doktor.

\section{Data, Instrumen, dan Teknik Pengumpulan Data}

Data yang digunakan berupa data primer dan data sekunder. Data primer diperoleh dari hasil analisa kuesioner yang diisi oleh mahasiswa program pascasarjana di Departemen ESL FEM IPB. Data sekunder diperoleh dengan metode kutipan dari berbagai sumber penelitian, buku, jurnal, artikel, Rencana Strategis Departemen ESL FEM IPB, laporan tahunan Departemen ESL FEM IPB dan sumber-sumber lain yang relevan dengan penelitian. Tabel 2 menyajikan jenis dan sumber data dalam penelitian.

Analisis data untuk menjawab tujuan penelitian digunakan secara kuantitatif dan deskriptif. Pengolahan data dilakukan dengan memakai software Microsoft Excel 2013 dan SPSS ver.24.0. Metode analisis dan pengumpulan data untuk tiap-tiap tujuan penelitian beserta outputnya dapat dilihat pada Tabel 3.

Variabel yang digunakan pada penelitian adalah variabel independen (X) dan variabel dependen (Y) sebagai berikut:

Variabel Independen (X)

Variabel independen yaitu variabel yang memengaruhi atau yang menjadi sebab perubahannya variabel dependen (Sugiyono 2007). Variabel independen yang dijadikan penelitian adalah faktor Program Studi dan faktor dukungan eksternal.

Faktor Program Studi

1. Produk (Product)

Produk adalah Program Pascasarjana yang ditawarkan pada mahasiswa untuk dapat memenuhi kebutuhan dan keinginannya. Program Studi Pascasarjana di Departemen ESL FEM IPB yang ditawarkan dengan program yang kompetitif, unik dan terbaik, terakreditasi, kurikulum sesuai yang 
diinginkan dunia kerja dan perkembangan ilmu pengetahuan.

\section{Harga (Price)}

Elemen harga dalam bauran pemasaran jasa Program Pascasarjana adalah biaya yang seharusnya diberikan mahasiswa kepada perguruan tinggi untuk memperoleh jasa pendidikan Pascasarjana di Program Studi yang dipilihnya. Program Studi Pascasarjana di Departemen ESL FEM IPB yang ditawarkan dengan harga yang dapat dijangkau dan tersedianya beasiswa.

\section{Promosi (Promotion)}

Promosi adalah seluruh alat yang dapat digunakan untuk sarana penyampaian informasi dan meyakinkan calon mahasiswa mengenai keunggulan perguruan tinggi dan pendidikan Program Pascasarjana yang dimiliki oleh Program Studi. Promosi Program Studi Pascasarjana di Departemen ESL FEM IPB dilakukan melalui surat kabar, media massa, spanduk, leaflet, brosur, baliho, website Sekolah Pascasarjana IPB dan Departemen, pameran pendidikan, media sosial.

\section{Lokasi (Place)}

Lokasi merupakan lokasi dan lingkungan perguruan tinggi, serta metode pemberian jasa pendidikan Program Pascasarjana. Lokasi Program Studi
Pascasarjana di Departemen ESL FEM IPB yang strategis dan tersedianya sarana transportasi, dekat dengan pusat pemerintahan dan bisnis.

5. Proses (Process)

Proses adalah rangkaian aktivitas yang dilaksanakan oleh Perguruan Tinggi dalam penyampaian jasa pendidikan Program Pascasarjana kepada mahasiswa. Program Studi Pascasarjana di Departemen ESL FEM IPB memberikan kemudahan dalam prosedur dan persyaratan penerimaan mahasiswa, proses pembelajaran dengan standar yang baik, proses pembimbingan dan penyelesaian tugas akhir dengan standar akademik yang baik, serta kemudahan proses layanan administrasi akademik dan pelayanan selainnya.

6. Orang (People)

Orang adalah semua orang/sumberdaya manusia yang dimiliki Perguruan Tinggi yang berperan dalam kegiatan penyampaian jasa pendidikan Program Pascasarjana kepada mahasiswa. Program Studi Pascasarjana di Departemen ESL FEM IPB memiliki SDM yang memiliki kualifikasi dan kompetensi dosen yang tinggi, dosen mampu membimbing dengan baik dan professional, serta pegawai yang memiliki kompetensi dan ketrampilan yang baik. 


\section{Bukti Fisik (Physical Evidence)}

Bukti fisik adalah semua hal yang ditawarkan dan bersifat fisik dari perguruan tinggi yang menunjukkan kualitas jasa pendidikan Program Pascasarjana. Program Studi Pascasarjana di Departemen ESL FEM IPB menyediakan lingkungan studi yang nyaman dan kondusif, ruang kuliah, laboratorium dan perpustakaan dengan sarana yang baik, tersedia poliklinik, kantin, kamar mandi, taman dan prasara pedukung lainnya yang memadai, serta tersedianya akses internet.

\section{Faktor Dukungan Eksternal}

1. Penugasan dari lembaga/instansi tempat bekerja

Penugasan dari lembaga/instansi calon mahasiswa secara langsung untuk meneruskan studi pada Program Studi yang disediakan oleh Program Pascasarjana di Departemen ESL FEM IPB.

\section{Ketersediaan sponsor}

Ketersediaan sponsor oleh penyandang sponsor yang diberikan kepada calon mahasiswa untuk kuliah pada Program Studi yang ada pada Program Pascasarjana di Departemen ESL FEM IPB.

\section{Kemauan sendiri}

Program Studi dipilih atas kemauan sendiri oleh calon mahasiswa sesuai dengan Program Pascasarjana yang telah disediakan.

Variabel Dependen (Y)

Sugiyono (2007) menyatakan bahwa variabel dependen adalah variabel yang dapat dipengaruhi atau yang dapat dijelaskan oleh variabel yang lain. Variabel tersebut adalah keputusan memilih Program Pascasarjana di Departemen ESL FEM IPB. Keputusan memilih pendidikan Program Pascasarjana pada perguruan tinggi adalah tindakan yang dilakukan mahasiswa dalam rangka menentukan pilihan Program Pascasarjana di Departemen ESL FEM IPB.

\section{Teknik Analisis Data}

Menurut Sugiyono (2007) deskriptif adalah statistik yang digunakan untuk menganalisis data dengan cara mendeskripsikan atau menggambarkan data yang telah terkumpul sebagaimana adanya tanpa bermaksud membuat kesimpulan yang berlaku untuk umum atau generalisasi. Analisis deskriptif digunakan untuk mengambarkan karakteristik responden mahasiswa. Karakteristik mahasiswa diuraikan berdasarkan jenis kelamin, program yang dipilih, usia, status bekerja, sumber biaya dan sumber informasi tentang pendidikan program pascasarjana di Departemen ESL FEM IPB. Analisis deskriptif juga digunakan untuk menggambarkan rangkaian pengambilan keputusan memilih pendidikan pascasarjana 
di Departemen ESL serta implikasi pengaruh faktor-faktor yang memengaruhi keputusan mahasiswa dalam upaya meningkatkan jumlah mahasiswa baru.

Analisis regresi linier berganda dimaksudkan untuk memperkirakan sejauhmana keadaan (naik turunnya) variabel dependen, bila dua atau lebih variabel independen dinaik turunkan (Sugiyono 2007). Analisis regresi digunakan juga untuk mengetahui faktor-faktor yang memengaruhi terhadap keputusan mahasiswa memilih Program Pascasarjana di Departemen ESL FEM IPB dengan rumus sebagai berikut:

$\Upsilon=\beta 0+\beta 1 \times 1+\beta 2 \times 2+\beta 3 \times 3+\beta 4 \times 4+\beta 5 \times 5$

$+\beta 6 \mathrm{x} 6+\beta 7 \mathrm{x} 7+\beta 8 \mathrm{x} 8+\beta 9 \mathrm{x} 9+\beta 10 \mathrm{x} 10+\mathrm{e}$

Keterangan :

$\Upsilon=$ Keputusan Mahasiswa

$\beta 0, \beta 1, \ldots \beta 10=$ Koefisien

$\mathrm{x} 1, \mathrm{x} 2, \ldots \mathrm{x} 10=$ Faktor Program Studi dan

faktor dukungan eksternal

e $=$ error, variabel gangguan

Pengujian secara parsial dipergunakan pada pengujian hipotesis dengan menggunakan t-stat. Apabila nilai t-stat $<\alpha$ $(\alpha=5 \%)$, maka variabel independen dinyatakan signifikan memengaruhi variabel dependen. Uji t berusaha untuk menunjukkan tingkat signifikansi dari konstanta dan tiaptiap variabel bebas terhadap model regresi (Setyaningsih et al. 2015).
Berbagai kajian penelitian terdahulu yang telah dikemukakan dan untuk menjawab tujuan dari penelitian, maka dapat dirangkai dan dijelaskan kerangka pemikiran penelitian pada Gambar 2.

\section{HASIL PENELITIAN DAN PEMBAHASAN}

\section{Hasil}

\section{Gambaran Umum Program Pascasarjana di Departemen ESL FEM IPB}

Departemen Ekonomi Sumberdaya dan Lingkungan diresmikan berdiri oleh Rektor IPB pada tanggal 10 Januari 2005 berdasarkan SK Rektor IPB No.101/K13/PP/2005. Departemen ESL sebagai salah satu unit yang berada di Fakultas Ekonomi dan Manajemen (FEM), Institut Pertanian Bogor (IPB). Departemen ESL merupakan departemen satu-satunya di Indonesia yang secara fokus mempelajari dan mengembangkan ilmu ekonomi pertanian, sumberdaya, dan lingkungan beserta dampak kegiatan ekonomi terhadap pertanian, sumberdaya, lingkungan, dan sosial. Departemen ESL mengelola Program Studi Sarjana (S1) Ekonomi Pertanian, Sumberdaya, dan Lingkungan (PS EPSL) dan Program Pascasarjana (Magister dan Doktor). Bidang keilmuan yang dikembangkan pada PS EPSL yaitu Ekonomi Pertanian, Ekonomi Sumberdaya, dan 
Ekonomi Lingkungan. Terdapat tiga (3)

Program Studi Pascasarjana di Departemen

ESL FEM IPB, yaitu Program Magister dan

Doktor Ilmu Ekonomi Pertanian (PS-EPN),

Program Magister dan Doktor Ekonomi

Kelautan Tropika (PS-EKT), dan Program

Magister Ekonomi Sumberdaya dan

Lingkungan (PS-ESL).

\section{Karakteristik Responden}

Karakteristik responden mahasiswa Program

Pascasarjana di Departemen ESL FEM IPB

berdasarkan hasil penelitian ditunjukkan pada tabel 4 .

Tabel 4 Jumlah dan persentase responden menurut karakteristik individu dan asal daerah

\begin{tabular}{ccccc}
\hline \multirow{2}{*}{$\begin{array}{c}\text { Karakteristik } \\
\text { Responden }\end{array}$} & \multicolumn{2}{c}{$\begin{array}{c}\text { Program } \\
\text { Magister }\end{array}$} & \multicolumn{2}{c}{$\begin{array}{c}\text { Program } \\
\text { Doktor }\end{array}$} \\
\cline { 2 - 5 } & $\begin{array}{c}\text { Freku } \\
\text { ensi }\end{array}$ & $\%$ & $\begin{array}{c}\text { Freku } \\
\text { ensi }\end{array}$ & $\%$ \\
\hline
\end{tabular}

Jenis Kelamin

Pria

Wanita

29

53,70

26

50 ,

\section{Usia}

$<25$ tahun

\section{5-30 tahun}

$25 \quad 46,30$

25

\section{0-35 tahun}

35-40 tahun

$>40$ tahun

22

40,74

16

40,74

0

29,63

$$
7
$$

12,96

$6 \quad 11,11$

3

5,56

Asal Daerah

\section{Jabodetabek}

Banten

Jawa dan Bali

Kalimantan

Maluku dan

Papua

Sulawesi

\begin{tabular}{lcccc} 
Sumatera & 11 & 20,37 & 14 & 27, \\
Tanzania & 1 & 1,85 & 0 & 0 \\
Status Bekerja & & & & \\
Belum bekerja & 22 & 40,74 & 1 & $\begin{array}{c}1,9 \\
\text { Sudah bekerja }\end{array}$ \\
S2 & 59,26 & 50 & 98, \\
\hline
\end{tabular}

\section{Proses Pengambilan Keputusan Mahasiswa}

Mahasiswa dalam memutuskan memilih Program Pascasarjana di Departemen ESL FEM IPB memiliki berbagai alasan yang mendasarinya. Alasan yang mendasari mahasiswa memilih Program Magister di Departemen ESL FEM IPB berdasarkan hasil penelitian dapat ditunjukkan pada Tabel 5.

Tabel 5 Alasan mahasiswa melanjutkan Program

Pascasarjana di Departemen ESL 
Impian kuliah di salah satu perguruan tinggi terbaik

4.15

4.18

Menurut Sumarwan (2015) bahwa pencarian informasi mulai dilakukan ketika konsumen memandang bahwa kebutuhan bisa dipenuhi dengan membeli dan mengkonsumsi suatu produk. Gambaran sumber informasi yang digunakan mahasiswa dalam penelusuran informasi tentang Program Studi Pascasarjana di Departemen ESL FEM IPB ditunjukkan pada Tabel 6.

Tabel 6 Sumber informasi yang digunakan

\begin{tabular}{|c|c|c|}
\hline \multirow[t]{2}{*}{ Sumber Informasi } & $\begin{array}{l}\text { Program } \\
\text { Magister }\end{array}$ & $\begin{array}{c}\text { Program } \\
\text { Doktor }\end{array}$ \\
\hline & $\%$ & $\%$ \\
\hline Website SPs IPB & 56.86 & 76.47 \\
\hline Mahasiswa $\quad$ Program & 13.73 & 13.73 \\
\hline Pascasarjana & & \\
\hline $\begin{array}{l}\text { Departemen ESL FEM } \\
\text { IPB }\end{array}$ & & \\
\hline Internet & 31.37 & 21.57 \\
\hline $\begin{array}{l}\text { Website Departemen ESL } \\
\text { FEM IPB }\end{array}$ & 29.41 & 11.76 \\
\hline Alumni SPs IPB & 17.65 & 21.57 \\
\hline Keluarga & 3.92 & 1.96 \\
\hline Mahasiswa SPs IPB & 21.57 & 9.80 \\
\hline Alumni $\quad$ Program & 21.57 & 15.69 \\
\hline Pascasarjana & & \\
\hline $\begin{array}{l}\text { Departemen ESL FEM } \\
\text { IPB }\end{array}$ & & \\
\hline Televisi dan Radio & 0 & 0 \\
\hline Atasan & 5.88 & 5.88 \\
\hline PPMB & 13.73 & 3.92 \\
\hline $\begin{array}{l}\text { Brosur, Leaflet, Poster, } \\
\text { Spanduk }\end{array}$ & 11.76 & 11.76 \\
\hline Surat Kabar dan Majalah & 0 & 0 \\
\hline Pendidikan & 3.92 & 1.96 \\
\hline Program Pascasarjana di & & \\
\hline $\begin{array}{l}\text { Departemen ESL FEM } \\
\text { IPB }\end{array}$ & & \\
\hline Teman & 17.65 & 19.61 \\
\hline Lainnya & 3.92 & 3.92 \\
\hline
\end{tabular}

Upaya mahasiswa dalam rangka mencari informasi yang berkaitan dengan Program Studi sebagai bahan pertimbangan sebelum menentukan pilihan, berdasarkan hasil penelitian lima urutan informasi yang paling banyak dicari dan dipertimbangkan oleh mahasiswa Program Pascasarjana Departemen ESL FEM IPB ditunjukkan pada Tabel 7.

Tabel 7 Informasi yang dicari dan dipertimbangkan

\begin{tabular}{lcc}
\hline \multicolumn{1}{c}{ Informasi } & $\begin{array}{c}\text { Program } \\
\text { Magister }\end{array}$ & $\begin{array}{c}\text { Program } \\
\text { Doktor }\end{array}$ \\
\cline { 2 - 3 } & $\%$ & $\%$ \\
\hline Pilihan Program Studi & 64.81 & 78.43 \\
Lokasi Kampus & 25.93 & 27.45 \\
Kualifikasi dan & & \\
Kompetensi Dosen & 64.81 & 62.75 \\
Akreditasi Program Studi & & \\
dan Institusi & 51.85 & 43.14 \\
Kegiatan Kemahasiswaan & 3.70 & 5.88 \\
Biaya Pendidikan & 16.67 & 17.65 \\
Prosedur dan Persyaratan & & \\
Pendaftaran & 22.22 & 21.57 \\
Kerjasama Pendidikan & & \\
Dalam dan Luar Negeri & 7.41 & 3.92 \\
Kurikulum Program Studi & 27.78 & 29.41 \\
Beasiswa Pendidikan & 11.11 & 45.1 \\
Fasilitas dan Lingkungan & & \\
Pendidikan & 12.96 & 15.69 \\
Lainnya, sebutkan & 3.70 & 0.00 \\
\hline
\end{tabular}

Responden atau mahasiswa sebelum memutuskan untuk melanjutkan studi pada Program Pascasarjana di perguruan tinggi mempertimbangkan perguruan tinggi yang lain sebagai alternatif pilihan. Perguruan tinggi yang dipertimbangkan mahasiswa dapat dilihat pada Tabel 8 . 
Tabel 8 Perguruan Tinggi yang dipertimbangkan mahasiswa

\begin{tabular}{lcccc}
\hline \multirow{2}{*}{ Perguruan Tinggi } & \multicolumn{2}{c}{ Pilihan 1 } & \multicolumn{2}{c}{ Pilihan 2 } \\
\cline { 2 - 5 } & $\begin{array}{c}\text { Freku } \\
\text { ensi }\end{array}$ & \% & $\begin{array}{c}\text { Freku } \\
\text { ensi }\end{array}$ & $\%$ \\
\hline Institut Pertanian & 85 & 80, & 15 & 14, \\
Bogor (IPB) & & 95 & & 29 \\
Institut Teknologi & 3 & 2,8 & 21 & 20, \\
Bandung (ITB) & & 97 & & 00 \\
Universitas Indonesia & 10 & 2 & 32 & 30, \\
(UI) & & 4,7 & 34 & 32, \\
Univeritas Gajah & 5 & 6 & & 38 \\
Mada (UGM) & & 1,9 & 3 & 2,8 \\
PT Lainnya & 2 & 0 & 3 & 6 \\
\hline
\end{tabular}

Mahasiswa dalam proses keputusan memilih

Program Studi Pascasarjana di Departemen

ESL FEM IPB sebagai tempat studinya, terdapat faktor-faktor yang mengintervensinya dalam membuat keputusan. Gambaran cara mahasiswa membuat keputusan dapat dilihat pada Tabel 9.

Tabel 9 Cara mahasiswa membuat keputusan

\begin{tabular}{lcc}
\hline Uraian & Frekuensi & $\mathbf{( \% )}$ \\
\hline Program Magister & & \\
Telah Direncanakan & 44 & 81,48 \\
Tidak Direncanakan & 10 & 18,52 \\
Program Doktor & & \\
Telah Direncanakan & 44 & 86,27 \\
Tidak Direncanakan & 7 & 13,73 \\
\hline
\end{tabular}

Mahasiswa sebelum memutuskan memilih Program Studi Pascasarjana di Departemen ESL FEM IPB, sebagian besar meminta pendapat dan rujukan dari orang lain. Kelompok acuan yang berpengaruh terhadap keputusan mahasiswa memilih Program Pascasarjana di Departemen ESL FEM IPB ditunjukkan pada Tabel 10.
Tabel 10 Pengaruh kelompok acuan terhadap keputusan mahasiswa

\begin{tabular}{|c|c|c|}
\hline Kelompok Acuan & Frekuensi & $\%$ \\
\hline \multicolumn{3}{|l|}{ Program Magister } \\
\hline Keluarga/Orang Tua & 34 & 62,96 \\
\hline Teman & 25 & 46,30 \\
\hline Dosen & 8 & 14,81 \\
\hline Dosen Pembimbing sebelumnya & 1 & 1,85 \\
\hline Atasan & 15 & 27,78 \\
\hline Kolega & 2 & 3,70 \\
\hline Internet & 1 & 1,85 \\
\hline Kedutaan Besar & 1 & 1,85 \\
\hline Ketua Program Studi & 1 & 1,85 \\
\hline Alumni & 0 & 0,00 \\
\hline Sendiri & 0 & 0,00 \\
\hline Tenaga Kependidikan & 0 & 0,00 \\
\hline \multicolumn{3}{|l|}{ Program Doktor } \\
\hline Keluarga/Orang Tua & 20 & 39,22 \\
\hline Teman & 22 & 43.14 \\
\hline Dosen & 4 & 7,84 \\
\hline Dosen Pembimbing sebelumnya & 3 & 5,88 \\
\hline Atasan & 27 & 52,94 \\
\hline Rektor & 0 & 0 \\
\hline Kolega & 1 & 1,96 \\
\hline Internet & 0 & 0 \\
\hline Kedutaan Besar & 0 & 0 \\
\hline Ketua Program Studi & 0 & 0 \\
\hline Alumni & 1 & 1,96 \\
\hline Sendiri & 3 & 5,88 \\
\hline Tenaga Kependidikan & 1 & 1,96 \\
\hline
\end{tabular}

Pasca Keputusan Memilih Program Studi Pascasarjana di Departemen ESL Tabel 11 menunjukkan gambaran tingkat kepuasan responden setelah menjalani pendidikan Pascasarjana di Departemen ESL FEM IPB.

Tabel 11 Tingkat kepuasan kuliah Program Pascasarjana di Departemen ESL

\begin{tabular}{lcccc}
\hline \multirow{2}{*}{$\begin{array}{c}\text { Tingkat } \\
\text { Kepuasan }\end{array}$} & \multicolumn{2}{c}{$\begin{array}{c}\text { Program } \\
\text { Magister }\end{array}$} & \multicolumn{3}{c}{$\begin{array}{c}\text { Program } \\
\text { Doktor }\end{array}$} \\
\cline { 2 - 5 } & $\begin{array}{c}\text { Frekuen } \\
\text { si }\end{array}$ & $\%$ & $\begin{array}{c}\text { Frekue } \\
\text { nsi }\end{array}$ & $\%$ \\
\hline \multirow{2}{*}{ Sangat Puas } & 14 & 25.9 & 16 & 31.3 \\
Puas & 30 & 55.5 & 30 & 58.8 \\
& & 6 & & 2 \\
Ragu-ragu & 9 & 16.6 & 3 & 5.88 \\
Tidak Puas & 1 & 1.87 & 1 & 1.96
\end{tabular}


Sangat Tidak Puas 0 0.00 2 3.92

Berdasarkan hasil penelitian, mahasiswa yang telah memilih kuliah pada Program Pascasarjana di Departemen FEM IPB bersedia memberikan rekomendasi kepada orang lain. Frekuensi tingkat kesediaan mahasiswa yang memberikan rekomendasi dapat dilihat pada Tabel 12.

Tabel 12 Tingkat kesediaan memberikan rekomendasi

\begin{tabular}{lcccc}
\hline \multirow{1}{*}{$\begin{array}{c}\text { Tingkat } \\
\text { Kesediaan }\end{array}$} & \multicolumn{2}{c}{$\begin{array}{c}\text { Program } \\
\text { Magister }\end{array}$} & \multicolumn{3}{c}{$\begin{array}{c}\text { Program } \\
\text { Doktor }\end{array}$} \\
\cline { 2 - 5 } & $\begin{array}{c}\text { Frekuen } \\
\text { si }\end{array}$ & $\%$ & $\begin{array}{c}\text { Frekue } \\
\text { nsi }\end{array}$ & $\%$ \\
\hline Sangat Bersedia & 15 & 27.7 & 16 & 31.3 \\
Bersedia & 35 & 64.8 & 32 & 62.7 \\
Ragu-ragu & 4 & 7.41 & 2 & 3.92 \\
Tidak Bersedia & 0 & 0.00 & 0 & 0.00 \\
Sangat Tidak & 0 & 0.00 & 1 & 1.96 \\
Bersedia & & & &
\end{tabular}

\section{Faktor-faktor yang Memengaruhi} Keputusan Mahasiswa Memilih Program Pascasarjana di Departemen ESL FEM IPB

Hasil analisis regresi faktor-faktor yang memengaruhi keputusan mahasiswa memilih Program Magister di Departemen ESL dapat dilihat pada Tabel 13.

Hasil analisis regresi faktor-faktor yang memengaruhi keputusan mahasiswa memilih Program Doktor di Departemen ESL dapat dilihat pada Tabel 14 .

\section{Pembahasan}

Tabel 4 menunjukkan jumlah dan persentase responden menurut karakteristik individu sesuai dengan jenis kelamin responden pria dan wanita Program Magister sejumlah $53,70 \%$ dan $46,30 \%$, sedangkan untuk Program Doktor sebesar 50,98 \% dan 49,02 \%. Hal tersebut dapat dinyatakan bahwa hampir sebagian besar yang memilih studi di Program Pascasarjana di Departemen ESL FEM IPB adalah responden berjenis kelamin laki-laki. Berdasarkan usia mayoritas responden yang memilih Program Magister berkisar $<25$ tahun $(40,74 \%)$ dan berusia 25-30 tahun (29,63\%), sedangkan Program Doktor usia mayoritas adalah 35-40 tahun $(39,22 \%)$ dan berusia $>40$ tahun $(31,37 \%)$. Dengan demikian dapat dinyatakan bahwa usia responden adalah produktif.

Berdasarkan asal daerah, untuk Program S2 responden terbanyak berasal dari Jabodetabek Banten (37,04 \%) dan Jawa dan Bali (29,63 \%). Responden Program Doktor yang terbanyak berasal dari Jabodetabek Banten $(35,29 \%)$ dan Sumatera $(27,45 \%)$, sehingga dapat dinyatakan bahwa responden yang mendominasi mengambil Program Studi Pascasarjana di Departemen ESL FEM IPB adalah dari Jabodetabek Banten. Hal ini berbanding nyata dengan hasil interview dengan beberapa mahasiswa yang berasal dari timur dengan jumlah hanya 1,85\% 
(Program Magister) dan 7,84 \% (Program Doktor), mereka kesulitan beradaptasi dengan beberapa mata kuliah dasar yang ada di IPB, seperti Statistika Dasar, Mikroekonomi, Matematika Ekonomi dan Makroekonomi. Kondisi tersebut Program Pascasarjana perlu memberikan matrikulasi atau pendalaman supaya mengurangi jumlah mahasiswa yang gagal. Berdasarkan status bekerja saat mendaftar di IPB proporsinya baik Program S2 dan S3 adalah sudah bekerja yaitu Magister 59,26 \% dan Doktor 98,04 \%. Dengan demikian dapat ditunjukkan bahwa rata-rata mahasiswa melanjutkan pendidikan Program Pascarsarjana adalah dalam rangka mengembangkan karir dan keilmuannya.

Proses pengambilan keputusan mahasiswa memilih Program Pascasarjana di Departemen ESL FEM IPB dilakukan dengan 5 (lima) langkah yaitu alasan yang mendasari melanjutkan pendidikan, informasi yang dicari, pertimbangan alternatif, memutuskan memilih, dan penilaian pasca memilih. Berdasarkan Tabel 5 menunjukkan bahwa alasan tertinggi yang mendasari mahasiswa melanjutkan pendidikan pada Program Magister adalah mengembangkan dan memperluas ilmu pengetahuan di bidang yang baru. Sedangkan alasan tertinggi yang mendasari mahasiswa Program Doktor melanjutkan pendidikan adalah meningkatkan pengetahuan, memahamkan dan keahlian di bidang pekerjaan yang digeluti.

Tahap pencarian informasi, pada Tabel 6 dapat dilihat bahwa sumber informasi yang terbanyak dimanfaatkan oleh mahasiswa baik Program Magister maupun Doktor untuk mencari informasi tentang Program Studi Pascasarjana di Departemen ESL adalah website Sekolah Pascasarjana IPB. Sedangkan informasi yang paling sering dicari dan dipertimbangkan oleh mahasiswa Program Magister dan Program Doktor untuk menempuh pendidikan adalah informasi tentang Program Studi (Tabel 7). Sebagian besar mahasiswa menyatakan bahwa Program Studi Pascasarjana di Departemen ESL merupakan program studi yang unik dan terbaik. Mayoritas mahasiswa juga menyatakan bahwa Program Studi Pascasarjana di Departemen ESL FEM IPB memiliki kurikulum yang berorientasi pada ekspansi ilmu pengetahuan dan cocok dengan pemenuhan tuntutan dunia kerja. Selain itu mayoritas mahasiswa juga menyatakan bahwa status akreditasi yang baik dan adanya kesempatan untuk mengikuti kerjasama pendidikan luar negeri pada Program Pascasarjana di Departemen ESL FEM IPB juga menjadi informasi yang banyak dicari dan menjadi pertimbangan mahasiswa.

Tabel 8 menunjukkan bahwa pada tahap evaluasi alternatif Program Pascasarjana di Departemen ESL FEM IPB 
menempati urutan pertama responden mempertimbangkannya sebagai tempat untuk meneruskan pendidikan. Kemudian diikuti oleh UGM untuk posisi kedua, posisi ketiga UI dan posisi keempat ITB. Tahap membuat keputusan melanjutkan pendidikan mayoritas responden menyatakan bahwa memilih Program Pascasarjana di Departemen ESL telah direncanakan sebelumnya. Pengaruh kelompok acuan terhadap pilihan Program Studi mayoritas responden menyatakan bahwa keluarga/orang tua (Program Magister) dan atasan (Program Doktor). Mayoritas responden pada tahap evaluasi pasca keputusan menyatakan puas menempuh kuliah pada Program Pascasarjana di Departemen ESL FEM IPB dan menyatakan mau untuk memberikan rekomendasi.

Faktor-faktor yang Memengaruhi Keputusan Mahasiswa Memilih Program Pascasarjana di Departemen ESL FEM IPB

Analisis penentuan mahasiswa memilih Program Studi Pascasarjana di Departemen ESL FEM IPB dikaji dengan menganalisis faktor-faktor yang memengaruhi keputusan mahasiswa menggunakan analisis regresi berganda. Berdasarkan hasil penelitian, model regresi linier berganda keputusan mahasiswa memilih Program Pascasarjana di Departemen ESL FEM IPB sebagai berikut:

\begin{tabular}{|c|c|c|c|c|c|}
\hline \multicolumn{2}{|c|}{ Program } & \multicolumn{3}{|c|}{ Model regresi } & $\begin{array}{l}\text { Faktor yang } \\
\text { signifikan } \\
\text { berpengaruh }\end{array}$ \\
\hline \multicolumn{2}{|c|}{ Magister } & \multicolumn{3}{|c|}{$\begin{array}{l}10.223+0.412 \underline{X}_{1} \\
+0.107 \quad X_{2}+ \\
0.045 X_{3}-0.036 \\
X_{4}+0.092 X_{5}+ \\
0.018 X_{6}-0.062 \\
X_{7}-0.027 X_{8}+ \\
0.023 X_{9}+0.316 \\
\underline{X}_{10}+e\end{array}$} & $\begin{array}{l}\text { Produk } \\
\text { (X1), } \\
\text { kemauan } \\
\text { sendiri } \\
(\mathrm{X} 10)\end{array}$ \\
\hline \multicolumn{2}{|c|}{ Doktor } & \multicolumn{3}{|c|}{$\begin{array}{l}3.593+0.325 \mathrm{X}_{1}+ \\
0.055 \mathrm{X}_{2}+0.035 \\
\mathrm{X}_{3}+0.198 \underline{X}_{4}+ \\
0.217 \mathrm{X}_{5}-0.044 \\
\mathrm{X}_{6}-0.207 \mathrm{X}_{7}+ \\
0.068 \mathrm{X}_{8}+0.037 \\
\mathrm{X}_{9}+0.306 \underline{X}_{10}+\mathrm{e}\end{array}$} & $\begin{array}{l}\text { Promosi } \\
(\mathrm{X} 4), \\
\text { kemauan } \\
\text { sendiri } \\
(\mathrm{X} 10)\end{array}$ \\
\hline \multicolumn{6}{|c|}{$\begin{array}{l}\text { Sumber: Hasil olahan data dengan SPSS } \\
\text { Ver.24. (2019) }\end{array}$} \\
\hline \multicolumn{6}{|c|}{ Keterangan: } \\
\hline Y & . & $\begin{array}{l}\text { Keputusan } \\
\text { Mahasiswa } \\
\text { Memilih }\end{array}$ & X6 & & SDM \\
\hline $\mathrm{X} 1$ & $:$ & $\begin{array}{l}\text { Produk } \\
\text { (Program } \\
\text { Studi) }\end{array}$ & $\mathrm{X} 7$ & : & $\begin{array}{l}\text { Bukti Fisik } \\
\text { dan } \\
\text { Lingkungan }\end{array}$ \\
\hline $\mathrm{X} 2$ & : & Harga & X8 & & Penugasan \\
\hline X3 & : & Lokasi & X9 & & Sponsor \\
\hline $\mathrm{X} 4$ & $:$ & Promosi & $\mathrm{X} 10$ & & $\begin{array}{l}\text { Kemauan } \\
\text { Sendiri } \\
\text { (Mahasiswa) }\end{array}$ \\
\hline X5 & : & Proses & $\mathrm{e}$ & : & $\begin{array}{l}\text { Variabel } \\
\text { random } \\
\text { error }\end{array}$ \\
\hline
\end{tabular}

1. Faktor yang memengaruhi keputusan mahasiswa memilih Program Magister

1) Produk

Variabel produk memiliki probabilitas signifikansi sebesar 0,046 lebih kecil dari taraf nyata 5\% sehingga produk berpengaruh signifikan terhadap keputusan mahasiswa memilih. 
Koefisien elastisitas positif sebesar 0,412 pada produk menunjukkan bahwa semakin tinggi kualitas produk (Program Studi), maka akan meningkatkan keputusan mahasiswa memilih Program Magister sejumlah 0,412. Berdasarkan hasil penelitian, mayoritas mahasiswa menyatakan bahwa informasi yang paling banyak dicari dan dipertimbangkan oleh mahasiswa untuk memutuskan memilih Program Magister di Departemen ESL FEM IPB adalah informasi tentang Program Studi.

2) Kemauan sendiri

Variabel kemauan sendiri memiliki probabilitas signifikansi sebesar 0,018 $<5 \%$ sehingga kemauan sendiri berpengaruh signifikan terhadap keputusan mahasiswa memilih pada taraf nyata 5\%. Koefisien elastisitas positif sebesar 0,316 pada kemauan sendiri (mahasiswa), artinya semakin besar kemauan sendiri mahasiswa terhadap Program Studi maka memotivasi mahasiswa memutuskan memilih Program Magister di Departemen ESL FEM IPB.

2. Faktor yang memengaruhi keputusan mahasiswa memilih Program Doktor

1) Promosi

Variabel promosi memiliki probabilitas signifikansi sebesar 0,042 lebih kecil dari taraf nyata 5\% sehingga produk berpengaruh signifikan terhadap keputusan mahasiswa memilih pada taraf nyata $5 \%$. Koefisien elastisitas positif sebesar 0,198 pada promosi, artinya semakin meningkatnya promosi oleh Program Doktor di Departemen ESL FEM IPB, maka akan menambah semangat mahasiswa untuk memutuskan memilih Program Doktor sebagai tempat melanjutkan pendidikannya sebesar 0,198.

2) Kemauan sendiri Variabel kemauan sendiri memiliki probabilitas signifikansi sebesar 0,001 $<5 \%$ sehingga kemauan sendiri memiliki pengaruh signifikan terhadap keputusan mahasiswa memilih pada taraf nyata 5\%. Koefisien elastisitas positif sebesar 0,306 pada kemauan sendiri, menunjukkan bahwa semakin besar kemauan sendiri terhadap Program Studi maka akan menyemangati mahasiswa memutuskan memilih Program Magister di Departemen ESL FEM IPB.

Berdasarkan hasil analisis regresi dapat dinyatakan bahwa nilai R Square (R2) dalam penelitian yang dilakukan pada Program Magister di Departemen ESL FEM IPB menunjukkan kebaikan model. Hal tersebut dapat dilihat pada nilai $\mathrm{R}$ Square (R2) sebesar 67,3\%, artinya bahwa keragaman 
variabel keputusan mahasiswa memilih Program Magister (Y) yang dapat dijelaskan oleh model sebesar $67,3 \%$ sisanya sebesar $32,7 \%$ diberikan penjelasan oleh faktor lain di luar model.

Hasil analisis regresi pada Program Doktor di Departemen ESL FEM IPB dapat dinyatakan bahwa nilai $R$ Square (R2) menggambarkan baiknya model. Hal tersebut dapat dilihat pada nilai $R$ Square (R2) sebesar $73,3 \%$, artinya bahwa keragaman variabel keputusan mahasiswa memilih Program Doktor (Y) yang dapat diberikan penjelasannya oleh model sebesar $73,3 \%$ sisanya sebesar $26,7 \%$ diterangkan oleh faktor lain di luar model.

\section{KESIMPULAN DAN IMPLIKASI}

\section{Kesimpulan}

Proses pengambilan keputusan mahasiswa dalam memilih Program Pascasarjana di Departemen ESL FEM IPB dilaksanakan dengan lima tahapan yaitu alasan yang mendasari melanjutkan pendidikan, pencarian informasi, evaluasi preferensi, penetapan memilih, dan pertimbangan setelah memilih. Faktor-faktor yang signifikan memengaruhi keputusan mahasiswa memilih Program Pascasarjana di Departemen ESL FEM IPB adalah produk, promosi dan kemauan sendiri.

\section{Implikasi}

Berdasarkan hasil penelitian, maka masukan yang bisa dikemukakan adalah perlu peningkatan koordinasi secara rutin dengan membentuk tim khusus promosi antara Sekolah Pascasarjana, Fakultas Ekonomi dan Manajemen, Departemen ESL FEM IPB dan Program Pascasarjana di Departemen ESL FEM IPB dalam usaha peningkatan jumlah mahasiswa.

\section{DAFTAR PUSTAKA}

Angipora, P.M. (2002). Dasar-Dasar Pemasaran. Jakarta: PT. Raja Grafindo Persada.

Arifin, Z.A.S., Sumarwan U., Najib M. (2017). Analysis of Factors Influencing Decisions Choosing the Graduate Program. Tesis. Institut Pertanian Bogor.

Artini, I.D.A.J., Kirya, I.K., Suwendra IW. 2014. Faktor-faktor yang Mempengaruhi Keputusan Mahasiswa dalam Memilih Jurusan di Fakultas Ekonomi dan Bisnis (FEB). e-Journal Bisma Universitas Pendidikan Ganesha Jurusan Manajemen, Volume 2 (2014).

Engel, J.F., Blackwell, R.D., Miniard, P.W., (1995). Perilaku Konsumen. FX Budiyanto, penerjemah. Jakarta: Binarupa Aksara. Terjemahan dari: Consumer Behaviour, Ed ke-6 jilid 2.

Erdawati. (2014). Pengaruh Motivasi, Persepsi dan Promosi terhadap Keputusan Mahasiswa Memilih STIE Pasaman Simpang Empat. E-Jurnal Apresiasi Ekonomi, Volume 2 (2014), 153-159.

Harahap, F., Satriawan, R.A., Hanif, R.H.A. (2015). Analisis Faktor-faktor yang 
Mempengaruhi Keputusan Mahasiswa dalam Memilih Jurusan Akuntansi sebagai Tempat Kuliah di Universitas di Kota Pekanbaru. JOM. FEKON. Volume 1 (2015), 1-12.

Harwani, Y., Budi, S., Rita, N., Gendut, S. (2018). Brand Name and Customers' Intention. European Research Studies Journal, Volume XXI, Issue 3 (2018), pp. 299- 315.

Hurriyati, R. (2015). Bauran Pemasaran dan Loyalitas Konsumen. Bandung (ID): Alfabeta.

Kotler, P. (2002). Manajmen Pemasaran. Edisi Milenium. Jakarta: Prenhalindo.

Marjanovic, B., Pavlovic, D.K. (2018). Factors Influencing The High School Graduates' Decision To Study Abroad: Toward A Theoretical Model. Journal of Contemporary Management Issues. Management, Volume 23 (2018), 221241.

Purwanto, Rahayu, H.C. (2014). Kontribusi Marketing Mix terhadap Keputusan Mahasiswa S1 untuk Memilih Kuliah di Universitas Pasir Pangaraian. Jurnal Ilmiah Cano Ekonomos, Volume 1 (2018), 21-40.

Rahardjo, S., Firdaus, M.R. (2015). Analisis Pengaruh Bauran Pemasaran Status Sosial Ekonomi Dan Motivasi Terhadap Keputusan Mahasiswa dalam Memilih Kuliah (Studi Pada Lembaga Pendidikan dan Pengembangan Profesi Indonesia (LP3i) Business CollegeCabang Banjarmasin). Jurnal Wawasan Manajemen, Volume 3, 1 (2015), 4659.

Setyaningsih, Juanda, B., Fariyanti, A. (2015). Faktor-faktor yang Mempengaruhi Ratio Non Performing Loan (NPL). Jurnal Aplikasi Bisnis dan Manajemen (JABM), Volume 1 (2015), 23-33.
Sugiyono. (2007). Metode Bisnis Penelitian. Cetakan kesepuluh. Bandung: CV Alfabeta.

Sukendar, M.U. (2015). Pengaruh Strategi Bauran Pemasaran Terhadap Keputusan Pemilihan Perguruan Tinggi Mahasiswa Program Studi D-3

Komunikasi Berbasis Multimedia Politeknik Indonusa Surakarta. Jurnal IKON, Volume 1 (2015), 18-27.

Sumarwan, U. 2015. Perilaku Konsumen:

Teori dan Penerapannya dalam Pemasaran. Ed ke-2 cetakan pertama. Jakarta: Penerbit Ghalia Indonesia.

Sumarwan, U., Fachrozi, A., Nursal, A., Nugroho, A., Nurzal, E.R., Setiadi, I.A., Suharyono, Alamsyah, Z. (2013). Pemasaran Strategik: Perspektif Value-Based dan Pengukuran Kinerja. Cetakan ketiga. Bogor: IPB Press.

Topan, T. ( 2018). Penawaran perkuliahan online. [internet]. [diunduh pada 2018 Des 12]. Tersedia pada: https://www.idntimes.com/life/educatio n/rosma-stifani/6-universitas-terbaikdi-indonesia-ini-tawarkan-programkuliah-online-lho-c1c2/full.

Wijaya, D. (2012). Pemasaran Jasa Pendidikan, Mengapa Sekolah Memerlukan Marketing. Jakarta: Salemba Empat.

Wiliana, E. (2018). Analisis Faktor-faktor yang Mempengaruhi Keputusan Mahasiswa dalam Memilih Program Studi di Fakultas Ilmu Kesehatan Universitas Muhammadiyah Tangerang. Jurnal JKFT, Volume 1 (2018), 71-78.

Wulandini, P., Saputra, R. (2017). Pengambilan Keputusan Mahasiswa dalam Memilih Perguruan Tinggi Swasta di Pekanbaru. Jurnal Sains Sosial dan Humaniora, Volume 1 (2017), 93-102. 
Tabel 2 Jenis dan sumber data penelitian

\begin{tabular}{|c|c|}
\hline Jenis Data & Sumber Data \\
\hline Pengenalan Kebutuhan & $\begin{array}{l}\text { Peningkatan kompetensi, menambah ilmu pengetahuan, } \\
\text { Peningkatan dan pengembangan karir, tuntutan pekerjaan, } \\
\text { dorongan keluarga, kepuasan dan kebanggan diri, status sosial, } \\
\text { jejaring, program studi yang diminati, biaya kuliah terjangkau, } \\
\text { tersedia beasiswa, kemudahan mengikuti program internasional. }\end{array}$ \\
\hline Pencarian Informasi & $\begin{array}{l}\text { Sumber informasi (website, keluarga, mahasiswa pasca, alumni, } \\
\text { televise, radio, atasan, panitia penerimaan mahasiswa, brosur, } \\
\text { leaflet, poster, spanduk, surat kabar dan majalah, pameran } \\
\text { pendidikan, teman) dan fokus perhatian (program studi, lokasi } \\
\text { kampus, kualifikasi dan kompetensi dosen, akreditasi program } \\
\text { studi, kegiatan kemahasiswaan, biaya pendidikan, prosedur dan } \\
\text { persyaratan pendaftaran, kerjasama pendidikan dalam dan luar } \\
\text { negeri, kurikulum program studi, beasiswa, fasilitas dan } \\
\text { lingkungan pendidikan). }\end{array}$ \\
\hline Evaluasi Alternatif & Perguruan Tinggi dan Program Studi yang dipilih. \\
\hline Proses Keputusan & $\begin{array}{l}\text { Cara memutuskan (direncanakan, tidak direncanakan), cara } \\
\text { mendaftar (Sistem PMB Online, daftar langsung, lewat pos), } \\
\text { rujukan pertimbangan memutuskan (keluarga, atasan, teman). }\end{array}$ \\
\hline Pasca Keputusan & $\begin{array}{l}\text { Seberapa puas (sangat puas, puas, tidak puas, sangat tidak puas, } \\
\text { ragu-ragu), rekomendasi (sangat bersedia, bersedia, tidak } \\
\text { bersedia, sangat tidak bersedia, ragu-ragu). }\end{array}$ \\
\hline Karakteristik Responden & $\begin{array}{l}\text { Nama, umur, jenis kelamin, asal daerah, pendidikan, pekerjaan, } \\
\text { instansi, pengalaman kerja. }\end{array}$ \\
\hline Faktor-faktor yang memengaruhi & Faktor bauran pemasaran dan faktor dukungan eksternal. \\
\hline Visi, Misi dan Tujuan & Visi, Misi dan Tujuan. \\
\hline Sejarah & Sejarah. \\
\hline Data Penerimaan Mahasiswa & Data jumlah mahasiswa. \\
\hline
\end{tabular}

Tabel 3 Matriks metode pengumpulan dan analisis

\begin{tabular}{|c|c|c|c|}
\hline Tujuan & $\begin{array}{c}\text { Metode Pengumpulan } \\
\text { Data }\end{array}$ & $\begin{array}{c}\text { Metode Analisis } \\
\text { Data }\end{array}$ & Output \\
\hline $\begin{array}{l}\text { 1. Mengkaji proses pengambilan } \\
\text { keputusan mahasiswa dalam } \\
\text { memilih program pascasarjana } \\
\text { di Departemen ESL FEM IPB }\end{array}$ & Primer dan sekunder & Deskriptif kuantitatif & $\begin{array}{l}\text { Proses pengambilan } \\
\text { keputusan mahasiswa }\end{array}$ \\
\hline $\begin{array}{l}\text { 2. Menganalisis faktor-faktor apa } \\
\text { saja yang memengaruhi } \\
\text { keputusan mahasiswa dalam } \\
\text { memilih Program Pascasarjana } \\
\text { di Departemen ESL FEM IPB }\end{array}$ & Primer & $\begin{array}{l}\text { Regresi berganda, } \\
\text { deskriptif kuantitatif }\end{array}$ & $\begin{array}{l}\text { Faktor-faktor yang } \\
\text { memengaruhi } \\
\text { mahasiswa memilih } \\
\text { Program } \\
\text { Pascasarjana }\end{array}$ \\
\hline
\end{tabular}




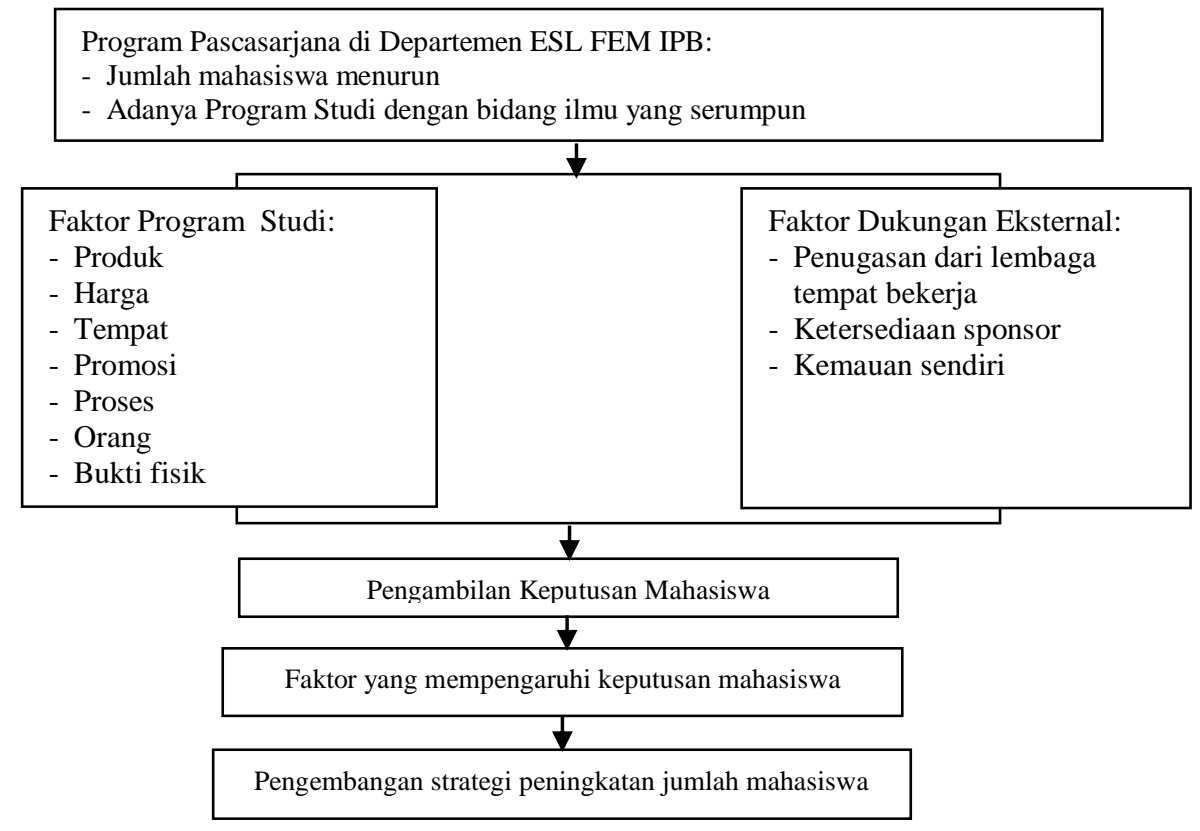

Gambar 2 Kerangka Pemikiran Penelitian

Tabel 13 Hasil uji regresi faktor-faktor yang memengaruhi keputusan mahasiswa memilih Program Magister di Departemen ESL

\section{Coefficients $^{\mathbf{a}}$}

\begin{tabular}{|c|c|c|c|c|c|c|c|c|}
\hline \multirow[b]{2}{*}{ Model } & & \multicolumn{2}{|c|}{ Unstandardized Coefficient } & \multicolumn{2}{|c|}{$\begin{array}{l}\text { Standardized } \\
\text { Coefficients }\end{array}$} & \multirow[b]{2}{*}{ Sig. } & \multicolumn{2}{|c|}{ Collinearity Statistics } \\
\hline & & $\overline{\mathrm{B}}$ & Std. Error & Beta & $\mathrm{t}$ & & Tolerance & VIF \\
\hline \multirow[t]{11}{*}{1} & (Constant) & 10.223 & 10.495 & & .974 & .335 & & \\
\hline & $\mathrm{X} 1$ & .412 & .201 & .361 & 2.050 & .046 & .245 & 4.075 \\
\hline & $\mathrm{X} 2$ & .107 & .102 & .118 & 1.053 & .298 & .603 & 1.659 \\
\hline & $\mathrm{X} 3$ & .045 & .114 & .049 & .393 & .696 & .488 & 2.050 \\
\hline & $\mathrm{X} 4$ & -.036 & .098 & -.039 & -.374 & .710 & .686 & 1.457 \\
\hline & $\mathrm{X} 5$ & .092 & .209 & .080 & .443 & .660 & .232 & 4.306 \\
\hline & X6 & .018 & .188 & .015 & .095 & .925 & .301 & 3.323 \\
\hline & $\mathrm{X} 7$ & -.062 & .141 & -.067 & -.442 & .661 & .328 & 3.050 \\
\hline & $\mathrm{X} 8$ & -.027 & .078 & -.051 & -.347 & .730 & .354 & 2.826 \\
\hline & X9 & .023 & .115 & .035 & .197 & .845 & .237 & 4.225 \\
\hline & $\mathrm{X} 10$ & .316 & .128 & .389 & 2.465 & .018 & .305 & 3.280 \\
\hline
\end{tabular}

$R$ Square $=.673 \quad$ Adjusted $R$ Square $=.597 \quad$ Durbin-Watson $=2.018$

a. Dependent Variable: Y

Sumber: Hasil olahan data dengan SPSS Ver.24. (2019) 
Tabel 14 Hasil uji regresi faktor-faktor yang memengaruhi keputusan mahasiswa memilih Program Doktor di Departemen ESL

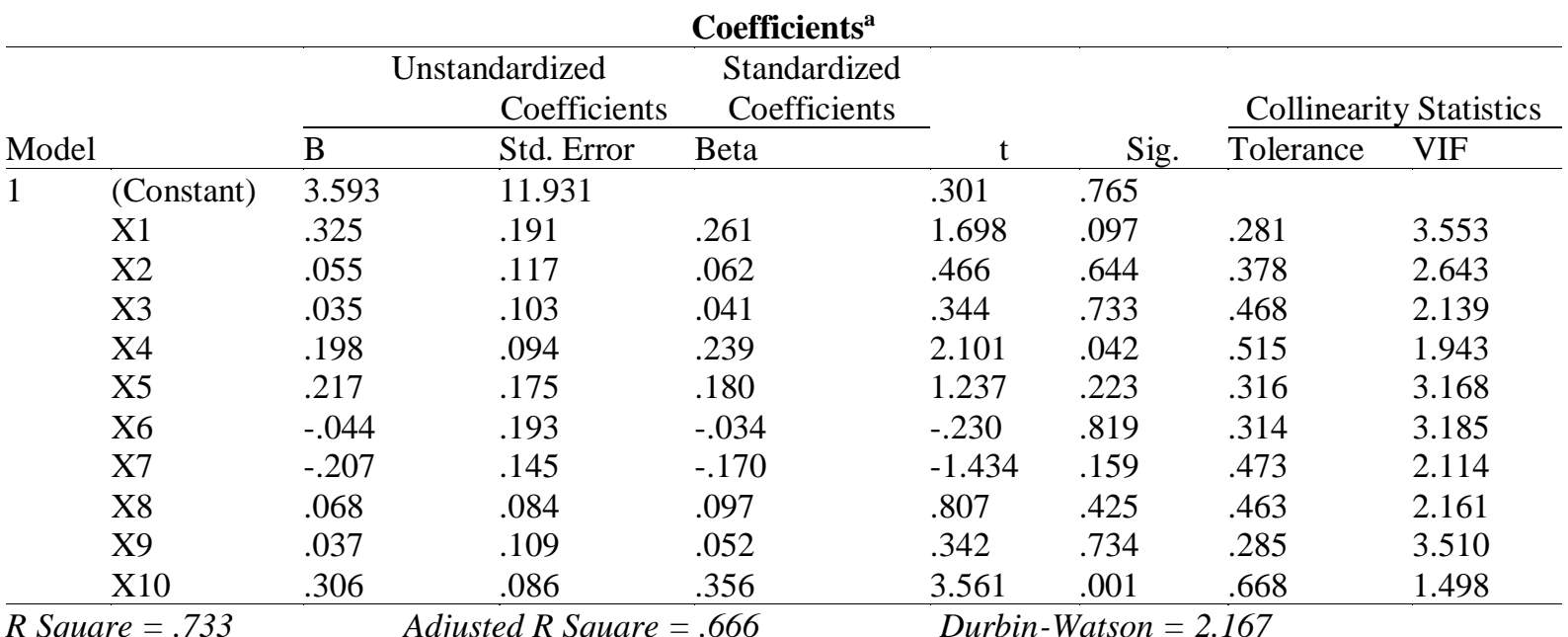

a. Dependent Variable: Y

Sumber: Hasil olahan data dengan SPSS Ver.24. (2019) 